\title{
Editor's choice: grapevine genetics are not just for researchers but also important to consumers
}

\author{
This article was published in the following Dove Press journal: \\ International Journal of Wine Research \\ I8 April 2013 \\ Number of times this article has been viewed
}

\author{
Roger M Pinder \\ International Journal of Wine \\ Research, York, UK
}

Correspondence: Roger M Pinder 2 St Wilfrid's Court, Monkgate, York YO3I 7UQ, UK

Tel +441904646684

Email roger.pinder@gmail.com
The genetic profiling of Vitis vinifera species has long been a rather esoteric interest of researchers investigating the family relationships between different wine grapes, partly as a surer way of identification than the traditional study of vine leaves known as ampelography. Two recent publications, each examining more than 1000 wine grape varieties, have expanded the field not only for the academic researcher ${ }^{1}$ but also for the consumer. ${ }^{2}$ The first publication has already been discussed in an editorial in this journal, ${ }^{3}$ but the latter is a newly published tome of more than 1200 pages authored by two distinguished Masters of Wine from the UK, Jancis Robinson and Julia Harding, and by the academic researcher José Vouillamoz from the University of Neuchatel, Neuchatel, Switzerland, who is responsible for the Swiss Vitis Microsatellite Database (SVMD). The new book covers not only the genetics of wine grapes but also viticultural characteristics, places of cultivation, and the various wines and their taste. Some of these factors are more important to wine consumers than to researchers.

Both publications show that inbreeding has limited wine grapes to a relatively small number of varieties sharing many incestuous relationships. Myles et al ${ }^{1}$ found that $75 \%$ of the 950 Vitis vinifera and 59 Vitis sylvestris varieties which they examined have direct family connections as parents, siblings, or offspring. Robinson, Harding and Vouillamoz ${ }^{2}$ divided their wine grape world of 1368 varieties into 14 closely related families, and named a mere handful of 'founder varieties' such as Pinot, Savagnin, Nebbiolo and Tribidrag as the ancestors of dozens of the many more familiar grapes that we know today. Indeed, the biodiversity of wine grapes is far less than we thought. ${ }^{3} \mathrm{Of}$ the 14 families, many are familiar to wine drinkers - Cabernet Sauvignon, Garganega, Muscat, Nebbiolo, Pinot, Refosco, Syrah and Tribidrag (Primitivo/Zinfandel) - while others are more obscure. Brianna has a complex pedigree, being a winter-hardy American hybrid derived from deliberate and natural crosses between 93 distinct parents involving nine Vitis species including Vitis vinifera. Cayetana Blanca is a very old variety from the Iberian peninsula, from which are derived 16 natural offspring in both Portugal and Spain. Completer is a rare Swiss variety which has undergone transalpine natural crossings with varieties in France and Ticino. Prié is now isolated in the Aosta valley of Italy but has many natural offspring in both Spain and Switzerland. Prior is a German hybrid from Baden-Würtemberg bred for disease resistance with a complex pedigree involving deliberate and natural crosses between 70 distinct parents from nine Vitis species including Vitis vinifera. Schiava Grossa from the Alto Adige 
area of northern Italy has been involved in both deliberate and natural crosses all over western Europe.

So what does this apparent biodiversity mean for consumers and researchers? It seems that consumers are happy that they have an almost infinite range of wine types from which to choose depending on the grape variety, the place of cultivation and the skill of the particular winemaker. They are interested in grape variety, and much of the world's wine, with some notable exceptions like France and Italy, is labeled with the appropriate varietal name. However, they are mostly unaware of how closely related are many of the most popular and esteemed varieties. For example, Cabernet Sauvignon is the progeny of Sauvignon Blanc and Cabernet Franc, while Merlot also has Cabernet Franc as a parent. Syrah is derived from two obscure varieties in the form of the white Mondeuse Blanche and the red Dureza, but is itself a full sibling of the white Rhône variety Viognier. Pinot Grigio and Pinot Gris are identical and are color variants of the same Pinot responsible for Pinot Blanc, Noir and Meunier. Sauvignon Blanc and Chenin Blanc are full siblings. While many consumers are now aware that Zinfandel and Primitivo are identical grapes, few realize that their origin lies in the Croatian variety Tribidrag. Despite its traditional homeland in Tuscany, Sangiovese is probably of mixed Tuscan and Calabrian parentage. Furthermore, a large proportion of Vitis vinifera grapes have undergone extensive cloning into diverse phenotypes, with Sangiovese and Pinot being amongst the most polyclonal of our esteemed wine grape varieties, offering the opportunity to make very different wines from what is apparently the same variety.

For researchers, the situation is a double-edged sword. On the one hand, the large variety and close relationships revealed by genetic profiling have stimulated interest in identifying the geographical origin of grape varieties and their spread around the world. On the other hand, concern has been raised by the lack of biodiversity as a result of inbreeding by largely vegetative propagation. Grapevines are all part of an extended pedigree, despite the substantial genetic diversity that has been maintained since the domestication of Vitis vinifera about 7000 years ago. Perhaps the so-far unidentified genetic nature of the numerous obscure varieties of grapevine, many of them from Eastern Europe and the Caucasus, may offer the prospect of greater biodiversity. Without it, there is a danger that new or old vine diseases could overwhelm entire populations; phylloxera and mildew have devastated vineyards over the centuries and are still with us in many parts of the world, while new pathogens abound. Wine grapevines are under severe pressure from an array of pathogens and are extensively treated with chemicals as a result. Although organic, biodynamic, and natural methods of cultivation have become more popular, they are still limited in use.

Genetic modification has clearly occurred in grapevine populations over the centuries by natural hybridization, witnessed by the lineage of many of our wine grape varieties. There is a very strong lobby against deliberate genetic modification in agriculture, particularly in Europe and especially in viticulture despite the advantages such technology could bring. More than a decade ago Meredith ${ }^{4}$ had suggested that targeted genetic modification of existing classic wine grape cultivars was already possible and could reduce disease loss and the use of chemical and other pesticides. More recently, Myles et $\mathrm{al}^{1}$ have indicated that genetic markers could be used to defend against pathogens by using genomic selection of the most resistant vines at the seedling stage rather than the current laborious procedure of selectively breeding thousands of seedlings in search of the most resistant vines. The focus remains for the moment on prevention of vine diseases and defense against pathogens. However, genetic modification could also replace the accidental crossing of Vitis vinifera species that has taken place in vineyards, and give rise to new species which combine the best taste characteristics of both parents when vinified.

Are the world's wine makers, wine drinkers and, perhaps more importantly, wine regulators ready for such innovation? ${ }^{3}$ Wine makers would perhaps welcome the chance to try out new varieties, especially in marginal areas and possibly in countries new to wine production such as the People's Republic of China and other parts of the Far East. Some innovators in the New World would certainly be willing to take a chance. The average consumer would probably savor the opportunity to experience novel tastes in new types of wine. Many wine writers, critics and connoisseurs, on the other hand, would doubtless be appalled. Regulators, particularly in heavily regulated markets like France and Germany, would not countenance such changes, and most of Europe would probably not allow even experimental plantings. The UK, whose small wine industry would benefit from genetically modified variants more suited to its marginal climate, is very antipathetic to such developments in agriculture in general. Nevertheless, wine from genetically modified grapevines has been around for centuries, and grapevine genetics is rapidly becoming as interesting for consumers as it clearly is to researchers. Watch this space.

\section{Disclosure}

The author reports no conflicts of interest in this work. 


\section{References}

1. Myles S, Boyko AB, Owens CL, et al. Genetic structure and domestication history of the grape. Proc Natl Acad Sci U S A. 2011;108(9): 3530-3535.

2. Robinson J, Harding J, Vouillamoz J. Wine Grapes. A Complete Guide to 1,368 Varieties, Including their Origins and Flavours. London, UK: Penguin Books; 2012:1242.
3. Pinder RM. Biodiversity of wine grapes: less than we thought. Int JWine Res. 2011;3:19-20.

4. Meredith CP. Grapevine genetics: probing the past and facing the future. Agric Conspec Sci. 2001;66(1):21-25.

International Journal of Wine Research

\section{Publish your work in this journal}

The International Journal of Wine Research is an international, peer-reviewed open-access, online journal focusing on all scientific aspects of wine, including: vine growing; wine elaboration; human interaction with wine; and health aspects of wine. The journal provides an open access platform for the reporting of evidence based studies on these topics. The manuscript management system is completely online and includes a very quick and fair peer-review system, which is all easy to use. Visit http://www.dovepress.com/testimonials.php to read real quotes from some of our published authors.

Submit your manuscript here: http://www.dovepress.com/international-journal-of-wine-research-journalisease-journal 